\title{
Effect of Infographics on Academic Performance, Attitude and Class Size of Undergraduate Students' in Media Systems
}

\author{
Nwosu Ebere Hope*, Williams Cheta \\ Department of Curriculum Studies and Educational Technology, Faculty of Education, University of Port Harcourt \\ *Corresponding author: ebere.nwosu@ymail.com
}

\begin{abstract}
The study ascertained the effect of infographics on class size, attitude and academic performance in Media Systems among undergraduate students of Curriculum Studies and Educational Technology, Faculty of Education of University of Port Harcourt. The study was guided by three (3) objectives, three research questions and three hypotheses. The population comprised of seventy-nine (79) three hundred (300) level students of Computer Science Education, while the sample of the study was made up of the whole seventy-nine (79) three hundred (300) level students of Computer Science Education purposively selected by the researcher. The research instrument was questionnaire structured by the researcher. The questionnaire consisted of twenty (20) items designed to determine student's attitude toward media systems. The data collected were analysed using Mean and standard deviation while t-test was used to analyse the hypotheses at 0.05 level of significance. The study revealed that there was significant difference in student's attitude on the use of infographics and on their academic performance in media system. There was also a significant difference in class size and their academic performance on the use of infographics in media systems. There was significant difference between male and female students' academic performance on use of infographics in media systems. As a result, the males performed better than the females. Males had a stronger affinity and interest towards the use of infographics in media systems. Recommendations were that teachers should be encouraged to use infographics during teaching and learning, the students should also be encouraged to develop positive attitude towards the use of infographics in their various courses. Also, parents should provide learning opportunities to their children especially their girls to enable them varieties in learning.
\end{abstract}

Keywords: infographics, class size, attitude, academic performance, media systems

Cite This Article: Nwosu Ebere Hope, and Williams Cheta, "Effect of Infographics on Academic Performance, Attitude and Class Size of Undergraduate Students' on Media Systems.” American Journal of Educational Research, vol. 6, no. 1 (2018): 83-87. doi: 10.12691/education-6-1-13.

\section{Background}

The teaching of media systems in schools is very important to students as society becomes global age. The new education system puts more emphasis on the outcomes which are known to be statements about knowledge, understanding, skills and attitudes and values that a learner should demonstrate as a result of a learning. This defines the curriculum in terms of what the learner should be able to do in a real-life context and what he needs to know and understand in order to do it [1]. This implies that students must be provide with basic educational skills that can be useful in the society and in any sphere of life. In media systems, teachers are effective in preparing the students of today for a meaningful life in the future, they must keep pace with changes, they must adapt new methods and constantly review their teaching techniques. A teaching aid or medium has no value in itself; its value is obtained through the manner in which it is applied or used. The teachers' didactic appreciation and initiative will always be the decisive factor whether the aid or medium will be successful.

The use of infographics in teaching and learning media systems play an important role in lives of students. Without such tool teaching remains teacher-centred and not learner centred. By making use of infographics in form of videos, experiments, plays/simulations learners are actively involved and learn to think critically. By making use of live specimen learners can connect it to real-life situations [2]. Infographics are learning tools that visually summarize large amounts of information. It can be as simple as a labelled graph or as complex as a story told in series of captioned pictures. As information becomes more prolific so have infographics;

1. Infographics are not new

2. Infographics can be simple or complex

3. Infographics all make information or data easy to access

The use of infographic has wide spread to the teaching and learning processes, and has become an essential tool in many spheres of life as to newspapers, magazines, traditional and digital media, which is comparable to 
social media such as Facebook, Instagram, Whatsapp, Skype, Twitter and YouTube in the educational significance of the dependence on visual communication rather than just using text [3]. Smiciklas [4] has defined Infographic as the delivery of information and ideas, data, text in a visual form to students faster in a manner for easy comprehension than traditional text methods. Kenner [3] illustrated that Infographic is an abbreviation of two terms, the information and graphs, and can be reached and designed through the integration of many variables such as text, pictures, flowcharts, graphs, videos, comics and other tools that relies on visual discernment.

\section{Features Infographic}

There are many features for infographic introduced by researchers [3-9] as the following:

1. It gives more visual attention for important information, so that they are more noticeable among the information represented graphically.

2. It organizes information in a logical way, make student's eye flow in tracking information in the correct order, making it easier to understand and find relationships between them.

3. A combination of signs, graphs, images, texts and colours help for better understanding of the content instead of text only based. So, infographic is an easy and natural way to reach out students with diverse learning styles.

4. Infographic depends on visual interactive activities and extensive use of multimedia, which raise students' motivation to learn and make learning activities more dynamic and realistic.

5. Visual imaging of information supports the teacher's position in the simplification of ideas and link it to everyday life and make learning meaningful and useful for students.

6. Interactive Infographic provides an opportunity for students to understand the facts and concepts just by looking, and link it to his visual memory in which he could retrieve it easily to build new experiences.

7. Infographic works to match the visual representation of information, thus achieving the principles of the teaching of mathematics, especially the principles of communication connections.

Visual learning is transfer of information through illustrations, photos, graphics, icons, videos, cartoons, comics and other visual expression [10]. Visual communication as one of the most important and most exciting learning tools is based on the pictures and drawings which accesses the student's mind and integrates text into visuals. Amongst the tools for visual communication include, Infographic, which allows the delivery of text, facts, ideas, knowledge, and skills on a wider scale, leads to a deeper understanding, and reduces the cognitive burden as a result of a focus on just a text. On that note, Infographic is considered to be one of the most important means of visual communication, which gained great popularity in recent times, as one of the most effective in the delivery of the information content in the digital age means [4].

For Infographic to be considered as an effective tool in teaching media systems, it must be prepared in such a way that it engages and captivates learners interest and also a way it will link between concepts and processes. Infographic focuses on the excitement, engagement of the learners and displays information in a simplified and fascinate manner to facilitate understanding of the information and lead to the satisfaction of the learner. Madar \& Buntat [11] believe that Infographics are important tools for learning any difficult or abstract concepts.

\section{Statement of the Problem}

Learners simply learn by memorizing facts passed on to them by the teachers without partaking in the learning process. Repositioning the teaching and learning of media system in schools through the use of infographics strategy was carried out in this study. Using infographics to learn enable meaningful learning, fasting as well as transferable to other contexts. Infographic is a strategy employed in $21^{\text {st }}$ century to engage and captivate learners in classroom, which is also interactive, challenging and huge potential for better teaching. It's very important to let students work on things in their own unique way. For young people who are mostly tactile and visual learners and can prepare their instructions creatively, auditory curriculum strategy is totally counterproductive. Therefore, the study sought to ascertain the effects of infographics as an instructional strategy on pre-service teachers' academic achievement, more so, how infographics can motivate their learning media systems.

\section{Purpose of the Study}

The main purpose of the study was to investigate the effect of infographics on class size, student's attitude and academic performance in media systems. Specifically, the study sought to:

1. Ascertain the extent to which student's attitude in the use of infographics affect their performance in media systems.

2. Find out the extent to which class size affects students' academic performance on the use of infographics in media systems.

3. Determine the extent to which gender affects student's academic performance in the use of infographics on media system.

\section{Research Questions}

Three research questions were posed for the study;

1. To what extent do student's attitudes in use of infographics affect their performance in media systems?

2. To what extent do class size affect student's academic performance on the use of infographics in media systems?

3. To what extent does gender affect student's performance on the use of infographics in media systems? 


\section{Hypotheses}

From the research objectives and research questions, the following research hypotheses were formulated at $\mathrm{P}<$ 0.05 level of significance.

1. There is no significant difference in student's attitude on their academic performance on the use of infographics in media systems.

2. There is no significant difference in class size on student's academic performance on the use of infographics in media systems.

3. There is no significant difference between male and female students' academic performance on the use of infographics in media systems.

\section{Research Design}

Descriptive survey design was used for the study.

\subsection{Population}

The population of this study consists of a total of seventy-nine (79) Computer Science Education third $\left(3^{\text {rd }}\right)$ year students of Department of Curriculum Studies and Educational Technology, Faculty of Education of University of Port Harcourt.

\subsection{Sample and Sampling Techniques}

The sample size consisted the entire population of seventy-nine (79) Computer Science Education third (3rd) year students in the Department of Curriculum Studies and Educational Technology, Faculty of Education, University of Port Harcourt, who are offering the course Media system 2017/2018 session. Purposive sampling technique was used.

\subsection{Instrumentation}

The research instrument was questionnaire designed by the researcher to determine the effect of class size on the use of infographics in media systems. The instrument consists of 20 items designed to determine student's attitude towards the use of infographics in media systems. The items in the questionnaires were structured on fourpoint Likert rating scale of Strongly Agree (SA) - 4, Agree (A) - 3, Disagree (D) -2 and Strongly Disagree $(\mathrm{SD})-1$

\subsection{Validity and Reliability of the Instrument}

Validity and Reliability of the 30 items achievement test developed by the researcher to cover the achievements related to Instructional Media and Instructional Design Models as a topic. The test was administrated to 30 preservice teachers of four hundred (400) level who had already studied the topics. The data obtained in the pilot have been analysed using ITEMAN3.0 (Item and Test Analysis) software. As a result of statistical analysis, item difficulty indexes, item discrimination indexes, test mean, standard deviation and reliability coefficient (KR-20) were calculated. The KR-20 coefficient was found to be .78 . The difficulty index of each item and discriminative index were also analysed differently. Face and content validity was used by the researcher. The Cronbach's alpha reliability coefficient of the 82 items attitude instrument was 0.92 , test-retest reliability coefficient was found to be 0.88. Cronbach's alpha values were calculated to determine the reliability of "Attitude Scale for media system”. The Cronbach's alpha value of the attitude was determined as .77.

\section{Data Analysis}

After the completion and collection of the questionnaires, the data were analysed using percentages, mean, standard deviation and t-test statistics to analyse the hypotheses at 0.05 level of significance using SPSS version 22.0.

Table 1. Mean and Standard Deviation responses of student's attitude towards the use of infographics in media systems

\begin{tabular}{|c|c|c|c|}
\hline $\mathbf{S} / \mathbf{N}$ & ITEMS & $\begin{array}{c}\text { Mean \& SD } \\
\text { of Males } \\
(\mathbf{n}=37)\end{array}$ & $\begin{array}{l}\text { Mean \& SD } \\
\text { of Females } \\
(n=42)\end{array}$ \\
\hline 1. & I like infographics & $6.74(3.96)$ & $1.38(0.48)$ \\
\hline 2. & $\begin{array}{l}\text { I feel insecure when I have to } \\
\text { deal with infographic materials }\end{array}$ & $\begin{array}{c}5.477 \\
(3.605)\end{array}$ & $1.91(1.27)$ \\
\hline 3. & $\begin{array}{l}\text { I am interested in learning } \\
\text { infographics. }\end{array}$ & $3.34(0.442)$ & $2.53(1.08)$ \\
\hline 4. & $\begin{array}{l}\text { I enjoy using infographics in } \\
\text { communicating with others }\end{array}$ & $13.65(7.85$ & $1.00(0.00)$ \\
\hline 5. & $\begin{array}{l}\text { Infographic skills make me more } \\
\text { employable. }\end{array}$ & $7.67(4.01)$ & $1.97(0.18)$ \\
\hline 6. & Infographics is worthless & $3.83(0.375$ & $1.45(0.74)$ \\
\hline 7. & $\begin{array}{l}\text { I find infographic concepts easy } \\
\text { to understand }\end{array}$ & $2.21(1.17)$ & $1.86(0.85)$ \\
\hline 8. & $\begin{array}{l}\text { I think infographics is a } \\
\text { complicated strategy }\end{array}$ & $2.05(1.01)$ & $1.12(0.32)$ \\
\hline 9 & $\begin{array}{l}\text { I feel distracted when } \\
\text { infographics is used in class }\end{array}$ & $2.11(1.09)$ & $1.21(0.40)$ \\
\hline 10. & $\begin{array}{l}\text { Infographics makes learning } \\
\text { easy }\end{array}$ & 2.75 (1.12) & $1.68(0.99)$ \\
\hline 11. & $\begin{array}{l}\text { I find it easy to explain text with } \\
\text { the use of infographics }\end{array}$ & $2.06(1.04)$ & $1.12(0.32)$ \\
\hline 12. & $\begin{array}{l}\text { Infographics is not needed for } \\
\text { anything }\end{array}$ & $3.83(0.38)$ & $1.06(0.24)$ \\
\hline 13. & $\begin{array}{l}\text { I like infographics and I can use } \\
\text { it for many things }\end{array}$ & $7.67(4.01)$ & $1.45(0.74)$ \\
\hline 14. & $\begin{array}{l}\text { The use of infographics is a } \\
\text { waste of time }\end{array}$ & $5.43(3.45)$ & $1.32(0.47)$ \\
\hline 15. & $\begin{array}{l}\text { The use of infographics makes } \\
\text { learning stimulating }\end{array}$ & $3.34(0.442)$ & $1.51(0.71)$ \\
\hline 16. & $\begin{array}{l}\text { Infographics makes one to be } \\
\text { more efficient in the use of } \\
\text { technology }\end{array}$ & $\begin{array}{l}16.636 \\
(5.507)\end{array}$ & 3.83 (0.38) \\
\hline 17 & $\begin{array}{l}\text { Infographics is used every day } \\
\text { by all }\end{array}$ & $2.06(1.04)$ & $1.91(1.27)$ \\
\hline 18 & $\begin{array}{l}\text { I am willing to participate in a } \\
\text { course when infographics is } \\
\text { used in the content }\end{array}$ & $\begin{array}{l}22.750 \\
(4.853)\end{array}$ & 7.67 (4.01) \\
\hline 19 & $\begin{array}{l}\text { I am willing to participate in a } \\
\text { course when the teacher uses } \\
\text { infographics. }\end{array}$ & $2.06(1.04)$ & $1.06(0.24)$ \\
\hline 20 & $\begin{array}{l}\text { I participate eagerly in a Course } \\
\text { that is abstract because } \\
\text { infographics are used }\end{array}$ & $3.43(0.15)$ & $1.12(0.32)$ \\
\hline
\end{tabular}


Table 2. t-test analysis on effect of student's attitude on the use of infographics in media systems

\begin{tabular}{|c|c|c|c|c|c|}
\hline Attitude & Mean & SD & Df & tcal & P 0.05 \\
\hline Positive & 22.45 & 7.2727 & 19 & 0.65034 & 0.5885 \\
\hline Negative & 23.95 & 5.65197 & 19 & 0.65034 & 0.5885 \\
\hline
\end{tabular}

Table 2 showed that the results on the effect of students' attitude on academic performance, t-calculated (0.65034) was greater than t-critical (0.5885) at 19 degree of freedom and 0.05 level of significance. Thus, the null hypothesis was rejected implying that there is a significant difference in student's attitude on their academic performance on the use of infographics in media systems. Thus, it could be deduced from the findings that student's attitude on the use of infographics affects their academic performance in media systems.

Table 3. t-test analysis of class size (big) effect on student's academic performance on the use of infographics in media systems

\begin{tabular}{|c|c|c|c|c|c|}
\hline Class Size (Big) & Mean & SD & Df & tcal & P 0.05 \\
\hline Positive & 3.2 & 3.83406 & 4 & 2.02516 & 0.1128 \\
\hline Negative & 10.4 & 4.3359 & 4 & 2.02516 & 0.1128 \\
\hline
\end{tabular}

It was observed in Table 3 that t-calculated (2.02516) was greater than t-critical (0.1128) at 4 degree of freedom and 0.05 level of significance. Therefore, the null hypothesis was rejected which implies that there is a significant difference in class size on student's academic performance on the use of infographics in media systems. The finding revealed that large class size affects student's academic performance.

Table 4. t-test analysis of small class size effect on student academic performance on the use of infographics in media systems

\begin{tabular}{|c|c|c|c|c|c|}
\hline Class Size (Small) & Mean & SD & Df & tcal & P 0.05 \\
\hline Positive & 13.2 & 1.48324 & 4 & 8.48528 & 0.0011 \\
\hline Negative & 1.2 & 1.78885 & 4 & 8.48528 & 0.0011 \\
\hline
\end{tabular}

On the effect of small class size as shown in Table 4, $\mathrm{t}$-calculated (8.48528) was also greater than t-cal (0.0011) at 4 degree of freedom and 0.05 level of significance. The null hypothesis was rejected and the results revealed that small class size do affect student's performance on the use of infographics in media systems.

The researchers are of the opinion that the poor performance in large class size may be due to the more restricted range of teaching and learning activities accorded to students in a large class as well as the reduced interaction. In the same vein, class size has preference to particular topics in media systems as practical is unfavourable in a large class, using chalk-talk method could be taught in a large class.

Table 5. t-test analysis of academic performance of male and female students on the use of infographics in media systems

\begin{tabular}{|c|c|c|c|c|c|}
\hline Gender & Mean & SD & Df & tcal & P 0.05 \\
\hline Males & 7.7 & 1.73205 & 3 & 0.75665 & 0.5043 \\
\hline Females & 6.25 & 1.70783 & 3 & 0.75665 & 0.5043 \\
\hline
\end{tabular}

As to gender effect, the result showed that $t$-calculated (0.75665) was greater than t-critical (0.5043) at 3 degree of freedom and 0.05 level of significance. Therefore, the null hypothesis was rejected implying that there is a significant difference between male and female students' academic performance on the use of infographics in media system. Hence, the finding revealed that male students perform better with the use of infographics in media systems than their female counterparts.

\section{Conclusion}

The findings suggest that students attitude towards the use of infographics in media systems affect their academic performance. Secondly, there was a significant difference in class size on academic performance of the students on the use of infographics in media systems. That is, both class sizes (big and small) affect student's performance on the use of infographics in media systems and finally we found a significant difference in academic performance on the use of infographics between male and female students where the male students performed better than their female counterparts. This implies that academic performance is gender bias. In summarizing our findings, we conclude that these results apply to only third $\left(3^{\text {rd }}\right)$ year undergraduate students of Curriculum Studies and Educational Technology, Faculty of Education, University of Port Harcourt.

\section{Recommendation}

In view of the findings from the study, the following recommendations are offered:

1. More instructional resources should be provided in classrooms to include power point slide board, public address system so that the students in a large class could be instructed as appropriate.

2. Attention should be given particularly to female students to make them improve on their academic achievement especially when using new instructional strategies to include infographics.

3. The use of infographics in classroom should be made mandatory as to facilitate learning and improve performance.

4. The study on student's attitude, class size and gender should be applied to other courses as to compare their findings.

\section{References}

[1] Branston, G. \& Stafford, R. (2013). The media student's book. 3d edition. London: Routledge. P 536.

[2] Jost, K.L. (1990). Computer-based interactive video: the potential for effective Instructional environments. Instructional development, 1 (3): 1621

[3] Kenner, S. (2014). Infographics best practices. Grasshopper Marketing.com. Retrieved from

http://grasshoppermarketing.com/infographics-best-practices/.

[4] Smiciklas M. (2012). The Power of Infographics: Using Pictures to Communicate and Connect with Your Audiences. Pearson Education, Inc.

[5] Balliette, A. (2011). The do's and don'ts of infographic design. Smashing Magazine. Retrieved from http://www.smashingmagazine.com/2011/10/14/the-dos-anddonts-of-infographicdesign.

[6] Lankow, J.; Ritchie, J.; Crooks, R. (201 2). Infographics: The Power of Visual Storytelling. Column Five Media, 1: 19-33. 
[7] Dick, H. (2014). The Future of Multimedia: Bridging to Virtual Worlds. Englewood Clifts, N. Jersey. Education Tchnology Publication.

[8] Dwyer, F.M.(2008). Effect of Knowledge of Objectives on visualized Instruction. Journal of Psychology, 77: 219-221.

[9] Davis, M., \& Quinn, D. (2013). Visualizing Text: The New Literacy of Infographics. Reading Today, 31(3), 16-27.
[10] Shafle, Afza Bt ; Janler, Joseflua Bamachea \& Ahmad, Wan Fatlmah Bt Wan (2009). Visual learning in application of integration, Visual Informatics: Bridging Research and Practice: First International Visual Informatics Conference, November, 832-843.

[11] Madar, A. and Buntat, Y. (2011). The effect of using visual graphics via interactive multimedia on learning of mathematics (Straight Line) at secondary school. Journal of Technical, Vocational \& Engineering Educational, 3: 94-103. 